\title{
Editorial: Carbon Bridge to the Arctic
}

\author{
Maria Vernet $^{1 *}$, Jacob Carstensen ${ }^{2}$, Marit Reigstad $^{3}$ and Camilla Svensen ${ }^{3}$ \\ ${ }^{1}$ Scripps Institution of Oceanography, University of California, San Diego, La Jolla, CA, United States, ${ }^{2}$ Department of \\ Bioscience, Faculty of Science and Technology, Aarhus University, Aarhus, Denmark, ${ }^{3}$ Department of Arctic and Marine \\ Biology, Faculty of Biosciences, Fisheries and Economics, UiT - The Arctic University of Norway, Tromsø, Norway
}

Keywords: European Arctic, Atlantic water inflow, primary productivity enhancement, climate change, Arctic carbon cycling, Arctic food webs, advective processes, carbon sink area

\section{Editorial on the Research Topic}

\section{Carbon Bridge to the Arctic}

Seasonality influences temporal and spatial variability in the Arctic Seas, controlled by daylength and modulated by sea ice extent. Under climate warming, incident light remains mostly unchanged, but changes in sea ice cover and melting as well as oceanic currents (Onarheim et al., 2014) regulate the ecosystem, its structure, and function. Results from the Research Topic "Carbon Bridge to the Arctic" indicate that a shorter ice-covered season to the west and north of the Svalbard Archipelago extends the growth season and sustains higher annual productivity, allows for Arctic species to have food for an extended period and for temperate species reaching the Arctic to survive and even reproduce further north. The inflow of Atlantic Water from the West Spitsbergen Current greatly modulates this region (WSC in Figure 1). The current has intensified over the last several decades (Schauer et al., 2004), causing the ocean heat transport and the water temperature to increase in Fram Strait and northern Barents Sea (Lind and Ingvaldsen, 2012; Polyakov et al., 2017; Lind et al., 2018). As the advective inflow contributes both nutrients and living biomass in the form of plankton (Hegseth and Sundfjord, 2008; Kosobokova and Hirche, 2009), the interaction of the West Spitsbergen Current with the sea ice edge additionally modifies the ecosystem at this Arctic gateway. This region is thus affected by polar climate, as reflected in changing sea ice conditions and also by southern climate through the Atlantic Water Inflow.

The Carbon Bridge project aimed at understanding the processes that impact productivity and carbon cycling along the gateway to the Arctic Ocean, characterizing ecosystem properties affected by sea ice in conjunction with organisms advected by the Atlantic Water Inflow. Field studies were carried out in eastern Fram Strait as well as north of the Svalbard Archipelago and the adjacent Arctic Ocean (Figure 1). This is the Arctic Ocean region experiencing the most prevailing sea ice decline (Onarheim et al., 2014). The Carbon Bridge comprised field measurements to test model predictions of substantial changes in productivity due to sea ice retreat in this region (Slagstad et al., 2015). In addition to the publications compiled in the Research Topic, the project provided policy makers, managers, stakeholders, and the general public with an understanding of the ecosystem and regime shifts that may develop in response to climate change (Wassmann, 2018).

The main findings, based on results from the Carbon Bridge project with the added contributions from the Hausgarten project (Nöthig et al., 2015), are summarized below highlighting the role of daylength as well as ice cover, advection, and meltwater input in shaping the structure and function of the pelagic ecosystem. This critical European Arctic region absorbs, transforms, and loses carbon by chemical and biological processes affecting biomass and composition of planktonic communities: 


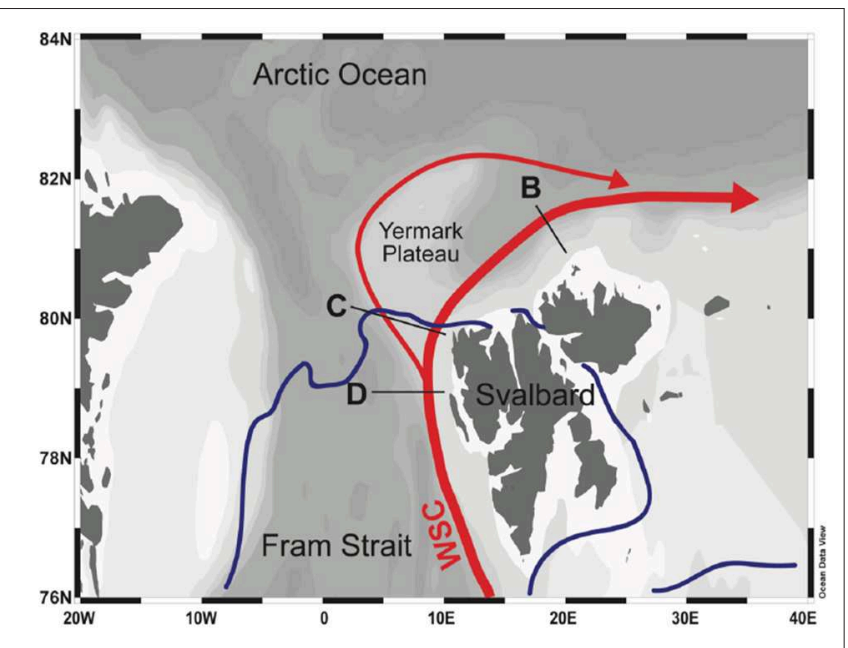

FIGURE 1 | The inflow of warm Atlantic Water into the Arctic Ocean where the West Spitsbergen Current (WSC) is a continuation of the North Atlantic Current through the Fram Strait. The WSC divides north of Svalbard, with the main branch following the Svalbard shelf break and another smaller branch flowing north of the Yermark Plateau. The Polar Front marks the boundary between Polar Water and Atlantic Water (blue line), with subduction of Atlantic Water Inflow that is found as a subsurface current throughout the Arctic Ocean (Rudels et al., 1996). Cruise transects for main cruises carried out in May and August 2014 are shown in black (identified as B, C, and D). Due to heavy sea ice conditions sampling north of Svalbard Archipelago was restricted.

\section{Seasonality of the primary producers and consumers}

Carbon pools characterizing the plankton abundance vary between 1 and 3 orders of magnitude between the spring bloom at the ice edge in comparison to the ice-free summer communities (Sanz-Martín, Vernet et al.). Thermal convection of warmer Atlantic Water north of Svalbard likely enhances vertical nutrient fluxes to the surface (Randelhoff et al.). Stratified water column conditions are provided by sea ice melt which leads to the development of the spring bloom (Chierici et al.; Randelhoff et al.). If the seasonality of phytoplankton primary production is divided into early-, peak-, decline-, and post-bloom stages, modeling suggests that both micro- and mesozooplankton shift from nearly pure herbivory (92-97\% of total food intake) during the early-bloom stage to an herbivorous, detritivorous, and carnivorous, or mixed, diet as the bloom progresses (Olli et al.). Overall, microzooplankton was the most important grazer, followed by copepods and nanoflagellates. Three Calanus species and the chaetognath Eukrohnia hamata constituted the bulk (or 90\%) of the mesozooplankton biomass in the West Spitsbergen Current with almost similar dominance by E. hamata, $C$. finmarchicus, and C. hyperboreus in the western Atlantic Water Inflow branch whereas $C$. finmarchicus dominated in the eastern and coastal branches, constituting there about half of the biomass (Carstensen et al.). Modeled losses of carbon sedimentation out of the euphotic zone increased gradually from 19\% (early phase) to $20 \%$ (peak phase) to $38 \%$ (late bloom phase) of the Gross Primary Production, with post-bloom phase presenting considerable variability (17-70\%) (Olli et al.). These modeled sedimentation rates are challenging to test: sediment traps provide information on the origin and sequestration of carbon with depth; however, when Particulate Organic Carbon (POC) vertical export is measured in the field, collected material in sediment traps varies with depth and particle sinking rates (Wekerle et al.). For phytoplankton, physiological differences in algal communities could affect productivity estimates. While productivity measured by oxygen production was higher than carbon uptake in the spring communities dominated by the colonial Phaeocystis pouchetti and diatoms, the summer communities of dinoflagellates and cryptophytes had higher carbon uptake than oxygen production, suggesting a variable Carbon:Oxygen ratio in Arctic photosynthesis (Sanz-Martín, Vernet et al.). In addition to nitrate, dissolved organic nitrogen (DON) was also an essential nitrogen source during the spring bloom at the sea-ice edge, decreasing in concentration from winter to spring faster than inorganic nitrogen sources (Paulsen et al.). In contrast, dissolved organic carbon (DOC) increased from spring toward the late bloom phase. This organic nutrient imbalance resulted in an asynchronous availability of carbon and nitrogen sources increasing the C:N ratio of the dissolved organic pool while maintaining Redfield ratios in the particulate organic pool.

\section{Seasonality of carbon balance}

The Atlantic Water Inflow entering the Arctic Ocean is enriched in carbon dioxide compared to the original North Atlantic waters, as the waters of the West Spitsbergen Current absorb through primary production more carbon dioxide $\left(\mathrm{CO}_{2}\right)$ than they release through respiration (Chierici et al.). Dissolution of calcium carbonate particles, either from advected shells or derived from sea ice, sustain $p \mathrm{CO}_{2}$ undersaturation in surface water. However, low carbon dioxide partial pressure conditions due to enhanced primary production produce episodic events of carbon limitation; gross primary production (GPP) increases from 32 to $72 \%$ with $\mathrm{CO}_{2}$ additions in spring, not in summer (Sanz-Martín, Chierici et al.). Loss rates through predation or geographic retention [locally or with Atlantic water recirculation toward the west, (Marnela et al., 2013; Hattermann et al., 2016)] exceeds the local production of mesozooplankton resulting in reduced Calanus finmarchicus biomass advected northward. Furthermore, food limitation could become more prevalent toward the north: carbon consumption north of Svalbard is higher than annual productivity converting this system into one of net heterotrophy (Carstensen et al.; Wassmann et al.). However, the pelagic food web retains energy resources-high community respiration always exceeds sedimentation losseswhich results in high efficiency of carbon transfer to higher trophic levels (Olli et al.).

3. Observed seasonal changes help predict ecosystem changes in the future Arctic

As the northern Svalbard Archipelago becomes ice-free, as predicted for the second half of the twenty-first century, present-day summer conditions are expected to become more widespread, affecting microbial dynamics and the biogeochemical cycling that they maintain. Autotrophic processes dominate in sea-ice associated communities in preand early-bloom conditions, while communities in ice-free 
conditions are considered post-bloom, with a prevalence of heterotrophy and recycled nitrogen sources (Olli et al.; Paulsen et al.; Sanz-Martin, Vernet et al.; Svensen et al.). As of today, eastern and western microbial communities in the Fram Strait demonstrate that changes in sea ice will affect ecosystem structure, as the diversity of bacteria and eukaryotes found associated with sea ice differs substantially from planktonic communities in ice-free waters (Fadeev et al.). Grazing of phytoplankton by microzooplankton will be enhanced in ice-free waters of the Svalbard region when summer-like planktonic communities prevail, consuming up to $79 \%$ of primary production (Lavrentyev et al.). Under ice-free conditions, Calanus finmarchicus and the small copepod Oithona similis may become more dominant, as they are able to feed and reproduce during extended periods of summer regenerated production, even when these conditions sustain low phytoplankton biomass (Svensen et al.).

4. Advection modulates seasonality of planktonic processes at this Arctic gateway

The transport of phytoplankton by the Atlantic Water Inflow increases in-situ primary production up to 50 times and enhances growth rates in the West Spitsbergen Current, compared to waters at the same latitude in the Greenland Sea (Vernet et al.). The advection affects phytoplankton production phenology, increasing early-spring carbon uptake in the West Spitsbergen Current and extending summer production north of Svalbard. The transports of water and zooplankton are decoupled, with minimum water transport in August and minimum zooplankton biomass transport in spring (Basedow et al.). Year round, a total of $18.8 \mathrm{~g} \mathrm{C} \mathrm{m}^{-2}$ year $^{-1}$ of mesozooplankton are advected, becoming available to predators. This advection increases 12 times the in-situ average secondary production north of Svalbard (Wassmann et al.).

If not the quantity, the nature of the advected carbon to the Arctic Ocean will change under climate warming. There was no multi-year trend in the variability in advected zooplankton biomass in the period 2001 to 2014. However, individual species show trends, with increases in biomass for Calanus finmarchicus and C. glacialis while Pseudocalanus sp. decreases (Carstensen et al.). While dissolved organic carbon (DOC) and chlorophyll a concentration have remained constant since 2009 in the West Spitsbergen Current, there has been a decrease in summer particulate organic carbon (POC), total organic carbon (TOC), and POC:TOC ratio suggesting a higher partitioning of carbon to the dissolved phase (Engel et al.). Increased abundance of amphipods, that was first discovered in this region during a warm anomaly in 2004-2007, persists to the present, with Thermisto compressa accounting for the most recent increase in total amphipod biomass (Schröter et al.). These results underlie the importance of investigations on the species level to detect responses to a changing climate.

5. Increased meltwater at the ice-ocean boundary can change the spatial variability of productivity in nearshore waters
Svalbard and Greenland are bordered by fjord systems with high freshwater input to the marine environment. These glacially-influenced fjords are considered hot-spots for carbon export to depth as silt in the meltwater acts as ballast for sinking particles (Seifert et al.). While fjord productivity is limited by seasonal light and nutrient supply, productivity increases toward the fjord mouth due to higher water transparency and increased nutrient supply from offshore waters (Hop et al.). The continued warming of the Atlantic Water Inflow is expected to increase the contribution of planktonic boreal species available at the fjord mouth, in concert with the increased pelagic production in the Arctic Ocean (Kahru et al., 2016). As distinct phytoplankton communities characterize the offshore Atlantic warm water and polar fjord waters (Hop et al.), increased glacier meltwater as a result of atmospheric and ocean warming will increment polar communities within nearshore waters, establishing a sharper gradient in species composition from the fjord's head toward offshore waters.

6. The Arctic Ocean will continue to store excess anthropogenic carbon dioxide

In concert with other regions of the Arctic Ocean, the waters of the West Spitsbergen Current act as a net sink of atmospheric $\mathrm{CO}_{2}$, absorbing more carbon than they release by $2.3 \mathrm{mmol} \mathrm{C} \mathrm{m}^{-2}$ year $^{-1}$ (Chierici et al.). For the Arctic Ocean, modeling efforts predict an increase of $1.0 \%$ to $2.3 \%$ in carbon storage in different climate scenarios (Slagstad et al., 2015; Armstrong et al.). Using integrated data to evaluate the ecosystem services in terms of economic value and change in carbon storage in the Arctic Ocean, it is possible to quantify a value of this region for the anthroposphere, highly relevant for future management and risk assessment. The estimates combine model runs with climate scenarios RCP 4.5 and RCP 8.5 from the Max Planck Institute (IPCC, 2014). This carbon storage is associated with an increased value of Arctic blue carbon from $€ 27.6$ billion to $€ 1$ trillion, when using social cost of carbon (SSC) and carbon market values from 2019 to 2099, respectively (Armstrong et al.).

In brief, the Carbon Bridge project demonstrated how the interaction among seasonal patterns in ecosystem processes, species-specific responses to climate warming, changes in sea ice distribution and advection of phyto- and zooplankton all result in enhanced food availability to higher trophic levels at the gateway to the Arctic Ocean.

\section{AUTHOR CONTRIBUTIONS}

MV wrote and edited the text. JC, CS, and MR contributed with writing and editing.

\section{ACKNOWLEDGMENTS}

We thank the Polar Program, Research Council of Norway, project No. 226415, for funding. 


\section{REFERENCES}

Hattermann, T., Isachsen, P. E., von Appen, W.-J., Albretsen, J., and Sundfjord, A. (2016). Eddy-driven recirculation of Atlantic Water in the Fram Strait. Geophys. Res. Lett. 43, 3406-3414. doi: 10.1002/2016 GL06832

Hegseth, E. N., and Sundfjord, A. (2008). Intreusion and blooming of Atlantic phytoplankton species in high Arctic. J. Mar. Syst. 24, 108-119. doi: 10.1016/j.jmarsys.2007.11.011

IPCC (2014). Climate Change 2014: Syntesis Report Contribution of Working Groups I, II and III to the Fifth Assessment Report of the Intergovernmental. Panel on Climate Change. Geneva: IPCC.

Kahru, M., Lee, Z., Mitchell, B. G., and Nevison, C. D. (2016). Effects of sea ice cover on satellite-detected primary production in the Arctic Ocean. Biol. Lett. 12:20160223. doi: 10.1098/rsbl.2016.0223

Kosobokova, K., and Hirche, H.-J. (2009). Biomass of zooplankton in the eastern Arctic Ocean - a base line study. Prog. Oceanogr. 82, 265-280. doi: 10.1016/j.pocean.2009.07.006

Lind, S., and Ingvaldsen, R. B. (2012). Variability and impacts of Atlantic Water entering the Barents Sea from the north. Deep Sea Res. Part I:Oceanogr. Res. Pap. 62, 70-88. doi: 10.1016/j.dsr.2011.12.007

Lind, S., Ingvaldsen, R. B., and Furevik, T. (2018). Arctic warming hotspot in the northern Barents Sea linked to declining sea-ice import. Nat. Clim. Change 8:634. doi: 10.1038/s41558-018-0205-y

Marnela, M., Rudels, B., Houssais, M. N., Beszczynska-Möller, A., and Eriksson, P. B. (2013). Recirculation in the Fram Strait and transports of water in and north of the Fram Strait derived from CTD data. Ocean Sci. 9, 499-519. doi: 10.5194/os-9-499-2013

Nöthig, E.-M., Bracher, A., Engel, A., Metfies, K., Niehoff, B., Peeken, I., et al. (2015). Summertime plankton ecology in Fram Strait-a compilation of longand short-term observations. Polar Res. 34:23349. doi: 10.3402/polar.v34. 23349
Onarheim, I. H., Smedsrud, L. H., Ingvaldsen, R. B., and Nilsen, F. (2014). Loss of sea ice during winter north of Svalbard. Tellus A 1:66. doi: 10.3402/tellusa.v66.23933

Polyakov, I. V., Pnyushkov, A. V., Alkire, M. B., Ashik, I. M., Baumann, T. M., Carmack, E. C., et al. (2017). Greater role for Atlantic inflows on seaice loss in the Eurasian Basin of the Arctic Ocean. Science 356, 285-291. doi: $10.1126 /$ science.aai8204

Rudels, B., Anderson, L. G., and Jones, E. P. (1996). Formation and evolution of the surface mixed layer and halocline of the Arctic Ocean. J. Geophys. Res. Oceans 101, 8807-8821. doi: 10.1029/96JC00143

Schauer, U., Fahrbach, E., Osterhus, S., and Rohardt, G. (2004). Arctic warming through the Fram Strait: Oceanic heat transport from 3 years of measurements. J. Geophys. Res. 109:C06026. doi: 10.1029/2003JC001823

Slagstad, D., Wassmann, P. F., and Ellingsen, I. (2015). Physical constrains and productivity in the future Arctic Ocean. Front. Mar. Sci. 2:85. doi: 10.3389/fmars.2015.00085

Wassmann, P. (2018) At the Edge... Current Knowledge from the Northernmost European Rim, Facing the Vast Expanse of the Hitherto Ice-Covered Arctic Ocean (Editor). Oslo: Orkana Publishing.

Conflict of Interest: The authors declare that the research was conducted in the absence of any commercial or financial relationships that could be construed as a potential conflict of interest.

Copyright (C) 2020 Vernet, Carstensen, Reigstad and Svensen. This is an open-access article distributed under the terms of the Creative Commons Attribution License (CC $B Y)$. The use, distribution or reproduction in other forums is permitted, provided the original author(s) and the copyright owner(s) are credited and that the original publication in this journal is cited, in accordance with accepted academic practice. No use, distribution or reproduction is permitted which does not comply with these terms. 